Cvetko Andreeski ${ }^{1}$, Slagjana Topuzoska ${ }^{2}$

UDC 368.91(497.11)

University Sv. Kliment Ohridski - Bitola

368.91(497.7)

Original Scientific Paper

Received: 06.11.2016.

Accepted: 29.11.2016.

\title{
STRUCTURAL ANALYSIS OF LIFE INSURANCE: A COMPARATIVE STUDY BETWEEN THE REPUBLIC OF MACEDONIA AND REPUBLIC OF SERBIA
}

\begin{abstract}
The development of life insurance is socially and financially the most important type of insurance for every country, because of the long-term coverage of the risks and savings components of this type of insurance. There are many research papers about the influence of determinants on the development of life insurance. In this paper we have done research on data related to life insurance offerings in the Republic of Serbia and the Republic of Macedonia. The research is comparative for the same determinants in each country context and their respective influences on life insurance.
\end{abstract}

KEYWORDS: life insurance, determinants, analysis

\section{Introduction}

Life insurance in the Republic of Macedonia and Republic of Serbia is not thought of as a new product, though it is also not yet present to the degree in which it is in developed countries. In some countries of Europe, in the USA, and in Japan, life insurance accounts for more than $50 \%$ of the total extent of insurance (Eliskovski M.), which provides greater security for the insured in the case of death or in encountering a specifically designated scenario after reaching a respective determined age, but also as a foundation for investment in different sectors.

\footnotetext{
${ }^{1}$ cvetko.andreeski@yahoo.com

2 slagjana.topuzoska@hotmail.com
} 
Many researchers have analyzed the development of life insurance in the global (Francois O.), a regional, or a national context (Andreeski, Milosevic, Njegomir and Eliskovski). In the literature corresponding to life insurance (Milosevic and Petrovic) can be seen a variety of determinants which affect life insurance. The most significant determinant is Gross Domestic Product, but there are also additional important determinants such as monetary politics, the development of social insurance, and the tendency to save, etc.

In the Republic Macedonia and the Republic Serbia we can find an increasing trend regarding the penetration of life insurance in the marketplace in recent years, though its presence is not yet in the range at which it is present in more developed countries, and is not yet competitive with certain developing countries, such as those which are members of the European Union. Based on the increase in the number of life insurance companies and their appearance on the insurance market, there is clear evidence of the development of life insurance in Macedonia and Serbia. In the following paper, an analysis is presented of the current state of life insurance in the Republic of Macedonia and the Republic of Serbia, as well as a structural analysis and an analysis of the impact of certain determinants on the development of life insurance. The results of this research are given in the text.

\section{Current State of the development of life insurance in the Republic of Macedonia and Republic of Serbia}

The condition of the development of life insurance in certain states is seen through two known parameters: 1) the degree of penetration of life insurance, which is reflected as a percent of the Gross Written Premium - GWP for life insurance in comparison with the Gross Domestic Product - GDP of the state, and 2) the density of life insurance, which is measured as a percent of the gross written premium for life insurance and the number of residents of the state. In Chart 1 the given values of life insurance penetration in certain regions of the world are presented along with the penetration of life insurance in the Republics of Macedonia and Serbia. 
Chart 1: Life insurance penetration in certain regions, Macedonia, and Serbia

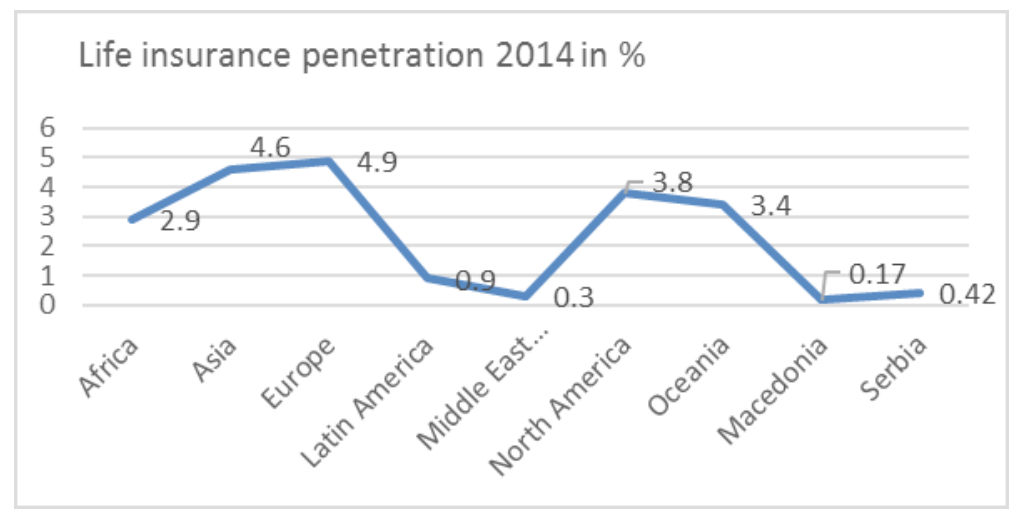

Source: Sigma Swiss Re and own calculations

From data it can be concluded that the degree of penetration of life insurance in the Republic of Serbia, and to an even greater extent in the Republic of Macedonia, is below the level of values corresponding to all regions shown, which indicates very low levels of penetration of life insurance in both markets.

In Chart 2 the values of the degree of penetration of life insurance in certain developing countries of Europe are shown.

Chart 2: Life insurance penetration for certain developing countries in Europe

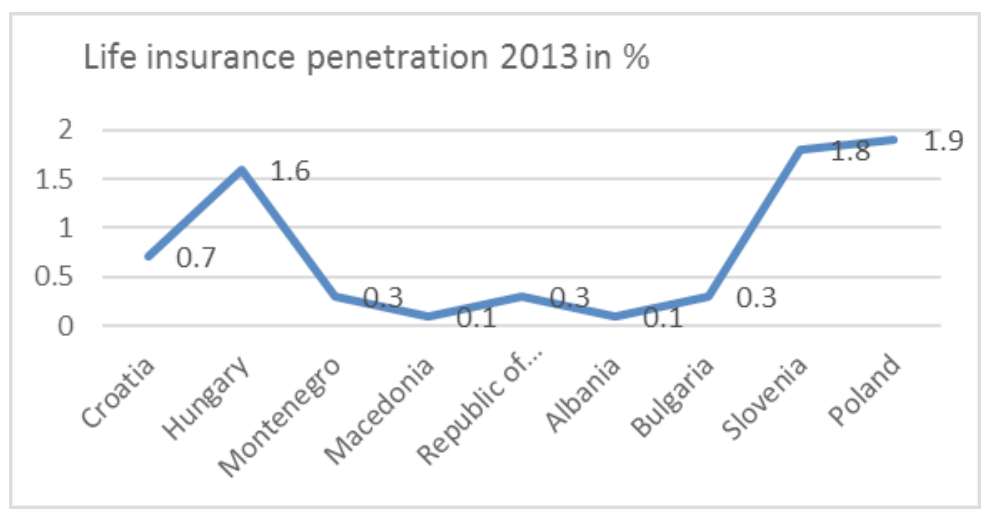

Source: Sigma Swiss Re 
From Chart 2 we can conclude that the degree of life insurance penetration in the Republic of Macedonia is equal to the degree of penetration in Albania, while in the Republic of Serbia the degree of life insurance penetration is on par with Montenegro and Bulgaria. Slovenia, Poland, and Hungary have a degree of life insurance penetration greater that $1.5 \%$, which indicates that they clearly have a more developed life insurance market than other developing countries in Europe.

Chart 3: Life insurance density in certain developing countries in Europe

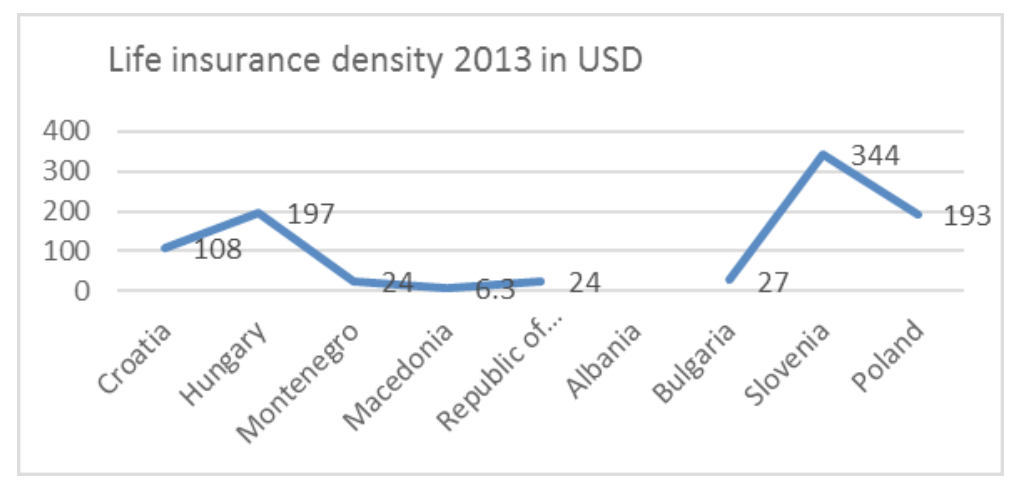

Source: Sigma Swiss Re and own calculations

Chart 3 presents the values of life insurance density for some of the developing countries of Europe that were presented in Chart 2. Amongst all analyzed countries, except for Albania, for which data could not be found, the density of life insurance in the Republic of Macedonia appears to be the lowest, while life insurance density in the Republic of Serbia is at the same level as in Montenegro and close to the level of Bulgaria.

These two parameters reflect the low level of development of life insurance in the Republic of Serbia, and indicate an even lower level in the Republic of Macedonia. In the following part of the paper, research was done regarding life insurance in the Republic of Macedonia and the Republic of Serbia over the last 10 years, as well as on determinants that have affected the development of life insurance in these two countries. 


\section{Development of life insurance in Macedonia and Serbia}

In Table 1 data are presented for the development of life insurance, as well as are data related to those determinants which have been proven as relevant for the development of life insurance (Andreeski, Milosevic and Eliskovski). From the data, without the need for additional analysis, it may be noted that the degree of life insurance penetration during the 10 year period analyzed has increased by 3.4 times. This is a significant increase, yet not a surprising result, as there was great potential for development. Also, we can make similar conclusions in evaluating life insurance density. The population of the Republic Macedonia did not increase as quickly as the development of life insurance. While in 2005 the life insurance density was 1.34 dollars, in 2014 it was 7.7 dollars, a measure 5.75 times as great.

Table 1: Development of life insurance, Gross domestic product, and index of living costs for the Republic of Macedonia, 2005 - 2014

\begin{tabular}{|l|r|r|r|r|r|r|r|r|r|r|}
\hline Macedonia & $\mathbf{2 0 1 4}$ & $\mathbf{2 0 1 3}$ & $\mathbf{2 0 1 2}$ & $\mathbf{2 0 1 1}$ & $\mathbf{2 0 1 0}$ & $\mathbf{2 0 0 9}$ & $\mathbf{2 0 0 8}$ & $\mathbf{2 0 0 7}$ & $\mathbf{2 0 0 6}$ & $\mathbf{2 0 0 5}$ \\
\hline $\begin{array}{l}\text { Gross written } \\
\text { premium - } \\
\text { life insurance }\end{array}$ & 888329 & 729459 & 598134 & 496995 & 354507 & 300817 & 266670 & 171206 & 115699 & 154174 \\
\hline $\begin{array}{l}\text { Total amount } \\
\text { of GDP }\end{array}$ & 7630733 & 7193501 & 7013622 & 6808264 & 6480874 & 6182401 & 6421489 & 6108839 & 5445239 & 5105405 \\
\hline $\begin{array}{l}\text { GDP in } \\
\text { million } \\
\text { denars }\end{array}$ & 525843 & 499560 & 466703 & 464187 & 437296 & 414622 & 414890 & 372889 & 334840 & 308447 \\
\hline $\begin{array}{l}\text { Degree of } \\
\text { penetration }\end{array}$ & 0,1689 & 0,14602 & 0,12816 & 0,10706 & 0,08106 & 0,07255 & 0,06427 & 0,04591 & 0,03455 & 0,04998 \\
\hline $\begin{array}{l}\text { Inflation } \\
\text { (index of } \\
\text { living costs }\end{array}$ & $-0,3$ & 2,8 & 3,3 & 3,9 & 1,3 & $-0,8$ & 8,3 & 2,3 & 3,2 & 0,5 \\
\hline
\end{tabular}

Source: Insurance Supervision Agency

To make a structural analysis of the development of life insurance, a correlation table was created which included the measures gross written premium, gross domestic product, and inflation, presented through the index of living costs. Values are given in Table 2. 
Table2: Correlation table

\begin{tabular}{|l|r|r|r|}
\hline & \multicolumn{1}{|l|}{ GWP } & \multicolumn{1}{l|}{ GDP } & \multicolumn{1}{l|}{ Inflation } \\
\hline GWP & 1 & 0,9358 & $-0,01667$ \\
\hline GDP & 0,9358 & 1 & $-0,189$ \\
\hline Inflation & $-0,0167$ & $-0,189$ & 1 \\
\hline
\end{tabular}

From the values compiled in Table 2, a significantly large and positive correlation between the gross written premium of life insurance in the Republic of Macedonia and gross domestic product can be established. Any correlation with inflation is minor and negative, which means that this determinant cannot be regarded as relevant for modeling a series of gross written premiums. If these values are compared with previous studies of life insurance in the Republic Macedonia (Andreeski, Milosevic, Njegomir), a growth in the correlation between the gross written premium for life insurance and gross domestic product is apparent.

A model was created for the gross written premium, in which as an independent variable is taken the gross domestic product and a constant. The results are given in Table 3 .

Table3: Results from the modeling of the gross written premium Dependent Variable: GWP

Method: Least Squares

Date: 07/10/15 Time: 18:57

Sample: 20052014

Included observations: 10

\begin{tabular}{lrlrr}
\hline \multicolumn{1}{c}{ Variable } & Coefficient & \multicolumn{1}{c}{ Std. Error } & t-Statistic & Prob. \\
\hline \hline \multicolumn{1}{c}{ C } & -1083339. & 200971.5 & -5.390510 & 0.0007 \\
\multicolumn{1}{c}{ GDP } & 3.516963 & 0.468399 & 7.508476 & 0.0001 \\
\hline \hline & 0.875732 & Mean dependent var & 407599.0 \\
R-squared & 0.860199 & S.D. dependent var & 262124.7 \\
Adjusted R-squared & 98008.35 & Akaike info criterion & 26.00035 \\
S.E. of regression & $7.68 \mathrm{E}+10$ & Schwarz criterion & 26.06087 \\
Sum squared resid & -128.0017 & Hannan-Quinn criter. & 25.93396 \\
Log likelihood & 56.37721 & Durbin-Watson stat & 0.565908 \\
F-statistic & 0.000069 & & \\
Prob(F-statistic) & & &
\end{tabular}


The variables have a high value in regard to t-statistics and according to these statistics, the probability of parameters rejection is close to zero. While the modeling of the series is good, Durbin-Watson statistics indicate a possible serial correlation of residual of the first order. After a residual analysis was completed with Correlogram, we found that the residuals are correlated and their values are not randomly distributed (Table 4). In the model an additional variable(s) is missing, which would allow for a valid model with uncorrelated residuals.

Table 4: Analysis of residuals

Date: 07/10/15 Time: 19:05

Sample: 20052014

Included observations: 10

\begin{tabular}{|c|c|c|c|c|c|c|}
\hline Autocorrelation & Partial Correlation & & $\mathrm{AC}$ & PAC & Q-Stat & Prob \\
\hline$\left.\cdot\right|^{* * *} \cdot \mid$ & $\cdot||^{* * *} \cdot \mid$ & 1 & 0.468 & 0.468 & 2.9201 & 0.087 \\
\hline $.1^{*} .1$ & $\cdot{ }^{*}||$. & 2 & 0.077 & -0.181 & 3.0101 & 0.222 \\
\hline.${ }^{* *}||$. &.${ }^{* *}||$. & 3 & -0.284 & -0.320 & 4.3906 & 0.222 \\
\hline$\cdot{ }^{* * *}|\cdot|$ & ${ }^{*} \mid .1$ & 4 & -0.407 & -0.171 & 7.6960 & 0.103 \\
\hline$\cdot{ }^{* * *}|\cdot|$ & $\cdot{ }^{* *}|\cdot|$ & 5 & -0.440 & -0.250 & 12.350 & 0.030 \\
\hline$\cdot{ }^{* *}||$. & $\cdot{ }^{*}||$. & 6 & -0.308 & -0.169 & 15.189 & 0.019 \\
\hline.$|\cdot|$ &.$|\cdot|$ & 7 & 0.005 & 0.069 & 15.190 & 0.034 \\
\hline $.1^{*} .1$ & ${ }^{*}||$. & 8 & 0.145 & -0.142 & 16.453 & 0.036 \\
\hline$\left.\cdot\right|^{* *} \cdot \mid$ & .1 .1 & 9 & 0.243 & -0.030 & 23.542 & 0.005 \\
\hline
\end{tabular}

The same analysis was made for data on the development of life insurance in the Republic of Serbia. The degree of the penetration of life insurance in the Republic of Serbia increased by 2.3 times over the past 10 years. 
Table 5: Development of life insurance, gross domestic product, and index for living costs in the Republic of Serbia, 2005 - 2014

\begin{tabular}{|c|c|c|c|c|c|c|c|c|c|c|}
\hline $\begin{array}{l}\text { Serbia, } \\
\text { percentage } \\
\text { participation } \\
\text { of life } \\
\text { insurance }\end{array}$ & 2014 & 2013 & 2012 & 2011 & 2010 & 2009 & 2008 & 2007 & 2006 & 2005 \\
\hline $\mathrm{T} 1$ & 22,2 & 18,4 & 17,2 & 16,0 & 13,9 & 12,8 & 10,3 & 7,9 & 7,4 & 8,3 \\
\hline $\mathrm{T} 2$ & 20,4 & 17,8 & 17,0 & 15,4 & 14,2 & 13,1 & 10,4 & 9,4 & 7,9 & 6,4 \\
\hline $\mathrm{T} 3$ & 20,9 & 18,8 & 17,6 & 15,8 & 14,8 & 13,5 & 10,9 & 10,4 & 8,7 & 7,3 \\
\hline yearly & 23,1 & 22,0 & 19,3 & 17,4 & 16,5 & 14,7 & 12,2 & 11,0 & 10,6 & 9,5 \\
\hline $\begin{array}{l}\text { Total } \\
\text { premium } \\
\text { million euro }\end{array}$ & 574 & 559 & 540 & 548 & 536 & 558 & 589 & 565 & 485 & 405.7 \\
\hline $\begin{array}{l}\text { GDP million } \\
\text { euro }\end{array}$ & 31590,9 & 34262,9 & 31683,1 & 33423,8 & 29766,3 & 30654,7 & 33704,5 & 29451,6 & 24434,6 & 21103,3 \\
\hline $\begin{array}{l}\text { Degree of } \\
\text { penetration }\end{array}$ & 0,41972 & 0,35893 & 0,32894 & 0,28528 & 0,29711 & 0,267581 & 0,2132 & 0,21102 & 0,21039 & 0,18263 \\
\hline $\begin{array}{l}\text { Inflation } \\
\text { (index for } \\
\text { living costs) }\end{array}$ & 2,2 & 1,7 & 12,2 & 7 & 10,3 & 6,6 & 8,6 & 11 & & \\
\hline
\end{tabular}

Source: National bank of Serbia, Insurance supervision sector

In Table 6 are given the values from the correlation matrix of data on the GWP, GDP, and Inflation.

Table 6: Correlation table

\begin{tabular}{|l|r|r|r|}
\hline & GWP & \multicolumn{1}{l|}{ GDP } & \multicolumn{1}{l|}{ Inflation } \\
\hline GWP & 1 & 0,90721 & $-0,36018$ \\
\hline GDP & 0,90721 & 1 & $-0,50857$ \\
\hline Inflation & $-0,36018$ & $-0,50857$ & 1 \\
\hline
\end{tabular}

From the values in Table 6, it can be noted that the degree of correlation between the gross written premium and gross domestic product in the Republic of Serbia is slightly weaker than the same correlation found in the Republic of Macedonia, though it is still significant. Inflation, as presented through the index of living costs, shows a higher degree of correlation with GDP than with the GWP. Because of this, inflation can't be included in the modeling of the GWP series. In Table 7 are presented the results of the GWP series model. 
Table 7:

Dependent Variable: GWP

Method: Least Squares

Date: 07/10/15 Time: 19:45

Sample: 20052014

Included observations: 10

\begin{tabular}{lrcrr}
\hline \hline \multicolumn{1}{c}{ Variable } & Coefficient & Std. Error & t-Statistic & Prob. \\
\hline \hline \multicolumn{1}{c}{ C } & 6656.737 & 1928.518 & 3.451737 & 0.0087 \\
\multicolumn{1}{c}{ GDP } & -0.191806 & 0.063705 & -3.010868 & 0.0168 \\
\hline \hline R-squared & 0.531213 & Mean dependent var & 901.1000 \\
Adjusted R-squared & 0.472615 & S.D. dependent var & 1109.220 \\
S.E. of regression & 805.5302 & Akaike info criterion & 16.39773 \\
Sum squared resid & 5191031. & Schwarz criterion & 16.45825 \\
Log likelihood & -79.98867 & Hannan-Quinn criter. & 16.33135 \\
F-statistic & 9.065324 & Durbin-Watson stat & 2.301699 \\
Prob(F-statistic) & 0.016791 & &
\end{tabular}

From the statistics given in Table 7, we can conclude that the correlation between the gross written premium and gross domestic product is substantially lower when compared to the model for the Republic of Macedonia, but the Durbin - Watson's statistic has a value close to 2, which means that there is a possible absence of a serial correlation of the residuals. Also, the criteria for model evaluation have lower values in comparison to the model for the Republic of Macedonia, which indicates that we have a better model. The correlation values of the residuals are given in Table 8 . We can see lower correlation values for the residuals, compared with the previous model. However, it's expected that if an additional valid variable were introduced, an even better model could be created. 
Table 8: Correlation values of the residuals

\begin{tabular}{|c|c|c|c|c|c|c|}
\hline Autocorrelation & Partial Correlation & & $\mathrm{AC}$ & PAC & Q-Stat & Prob \\
\hline$\cdot{ }^{* * *}|\cdot|$ & $\cdot{ }^{* * *}|\cdot|$ & 1 & -0.353 & -0.353 & 1.6601 & 0.198 \\
\hline.$* * 1.1$ & $\cdot{ }^{* * *}|\cdot|$ & 2 & -0.232 & -0.407 & 2.4652 & 0.292 \\
\hline$\left.\cdot\right|^{*} \cdot \mid$ & $\cdot{ }^{*}|\cdot|$ & 3 & 0.194 & -0.088 & 3.1125 & 0.375 \\
\hline .1 .1 & .1 .1 & 4 & 0.010 & -0.031 & 3.1144 & 0.539 \\
\hline$\cdot{ }^{*}|\cdot|$ & $\cdot{ }^{*}|\cdot|$ & 5 & -0.161 & -0.138 & 3.7331 & 0.588 \\
\hline$\cdot|\cdot|$ & $\cdot{ }^{*}||$. & 6 & 0.053 & -0.097 & 3.8187 & 0.701 \\
\hline$\cdot{ }^{*}|\cdot|$ & $\cdot{ }^{* *}|\cdot|$ & 7 & -0.145 & -0.342 & 4.6564 & 0.702 \\
\hline$\left.\cdot\right|^{*} \cdot \mid$ & $\cdot{ }^{*}|\cdot|$ & 8 & 0.139 & -0.112 & 5.8147 & 0.668 \\
\hline .1 .1 &.${ }^{*}||$. & 9 & -0.007 & -0.148 & 5.8198 & 0.758 \\
\hline
\end{tabular}

The test for normal distribution indicates that the sum of the residuals is near the value of 0 , and the probability of the acceptance of the residuals as an uncorrelated series is greater than $90 \%$.

\section{Conclusion}

Although significant progress in the development of life insurance in the Republic of Serbia and the Republic of Macedonia has been demonstrated, we cannot say that these countries are at the same level of the developing countries in the European Union, nor are they on par with the other measured regions of the world. To get closer to the developing countries in the European Union, the Republic of Serbia required an increase in the density of life insurance of no less than four times, and this increase in the Republic of Macedonia would have to be at least 16 times. In the last ten years, the density of life insurance in the Republic of Macedonia has increased 7.7 times, yet at this same rate of increase, it would take more than 20 years for the country to be relatively even with other developing countries in Europe.

As anticipated, the most influential determinant in the structure of the development of life insurance is gross domestic product. The correlation of this determinant with the gross written premiums in both countries is higher than 0.9. However, while this parameter is most relevant in modeling of the gross written premium, it is not enough for the creation of a valid model of the serial. For this to be achieved, 
additional parameter(s) are required which should not be in correlation with GDP and yet which would still be valid for the model.

In both counties we can find five sizable companies for life insurance, but we can say that according to measures of the development of life insurance, the Republic of Serbia has a more developed life insurance market. If the Republic of Macedonia continues with its recent rates of life insurance development, it will take ten years for it to reach the actual level of the development of life insurance currently in place in the Republic of Serbia.

\section{References}

1. Box, George E.P. Time Series Analysis - Forecasting and Control. New Jersey: Prentice-Hall, 1994.

2. Chatfield, C. The Analysis of Time Series - An Introduction (Fourth edition). London etc.: Chapman \& Hall, 1989.

3. Cvetko A., Bratislav M., Vladimir $\mathrm{Nj}$. Analysis of the Life Insurance Market in the Republic of Macedonia, Economic Annals, Volume LVII, No. 194 / July - September, Belgrade 2012

4. Francois O., Life Insurance in Developing Countries, A cross Country Analysis, UNCTAD/OSG/DP/93, December, 1994

5. Gujarati, Domodar N. Basic Econometrics (Third edition). New York etc.: McGraw-Hill, 1995.

6. http://www.stat.gov.mk/

7. http://www.swissre.com/sigma/

8. Tihomir J., Economics of Insurance, Euro-Mak Company DOO, Skopje, 2005 god.

9. Mills, Terence C. The Econometric Modelling of Financial Time Series. Cambridge: Cambridge University Press, 1993.

10. Stewart, Jon. Econometrics. New York etc.: Philip Allan, 1991.

11. www.aso.mk

12. www.nbrm.mk

13. www.nbs.rs

14. Bratislav M., Life and Health Insurance, entry for scientific research work, FTU - Ohrid, 2008

15. Vladimir Nj.., Insurance and Reinsurance, Tectus, Zagreb, 2011

16. The Annual Report for the Insurance Market in the Republic of Macedonia for the years 2005-2008 years. Ministry of Finance

17. The Annual Report for the State and Movement to the Insurance Market in the Republic Macedonia in the years 2009-2014. Insurance Supervision Agency

18. Zdravko P., Tomislav P., Life Insurance, Glosarium, Belgrade, 2003

19. Milan E.., "Economic Determinants of Consumption of Life Insurance in the Republic of Macedonia," Insurance Supervision Agency, August, 2011 